\title{
LANSIA ASIK, LANSIA AKTIF, LANSIA PODUKTIF
}

\author{
Siti Raudhoh, Dessy Pramudiani \\ Fakultas Kedokteran dan Ilmu Kesehatan Universitas Jambi \\ Corresponding author email: siti.raudhoh@unja.ac.id
}

\begin{abstract}
Elderly is someone who has entered the age of 60 years and over. Elderly is an age group in humans who have entered the final stage of their life phase. In the elderly, individuals experience a lot of problems, generally the elderly feel anxiety, loneliness, reduced emotional stability, and also experience dysfunction in their organs. This is because the elderly have physical limitations and have had traumatic experiences such as losing their family, children, spouse, and so on. Elderly community groups deserve the attention of all elements of government and the surrounding environment, but in reality elderly community groups are often ignored, and forgotten. Psychosocial support is needed to maintain emotional stability in the elderly and prepare for death. The provision of physical training in the form of elderly exercise and psychoeducation is given to encourage the elderly to remain happy and empowered even though they are no longer at their productive age.
\end{abstract}

Keywords: Gerontic Psychology, Elderly, Psychoeducation

\begin{abstract}
ABSTRAK
Lansia merupakan seseorang yang telah memasuki usia 60 tahun keatas. Lansia merupakan kelompok umur pada manusia yang telah memasuki tahapan akhir dari fase kehidupannya.Pada masa lansia individu mengalami banyak sekali permasalahan, umumnya lansia merasakan kecemasan, kesepian, berkurangnya stabilitas emosi, dan juga mengalami disfungsi terhadap organ tubuhnya. Hal-hal tersebut disebabkan karena lansia mempunyai keterbatasan fisik, serta mempunyai pengalaman yang traumatis seperti kehilangan keluarga, anak, pasangan, dan seterusnya. Kelompok masyarakat lanjut usia sudah sepatutnya menjadi perhatian oleh seluruh elemen pemerintahan maupun lingkungan sekitar, akan tetapi pada realitanya kelompok masyarakat lanjut usia sering kali ditepikan, dan dilupakan. Dukungan psikososial sangat diperlukan demi menjaga stabilitas emosi lansia, dan bersiap untuk menghadapi kematian. Pemberian latihan fisik berupa senam lansia dan psikoedukasi ini diberikan guna mengajak lansia untuk tetap bahagia, dan berdaya sekalipun tidak lagi berada pada usia produktif.
\end{abstract}

Kata Kunci : Lansia, Psikoedukasi, Kesehatan Lansia, Psikologi Gerontik

\section{PENDAHULUAN}

Lansia merupakan seseorang yang telah memasuki usia 60 tahun keatas. Lansia merupakan kelompok umur pada manusia yang telah memasuki tahapan akhir dari fase kehidupannya. Kelompok yang dikategorikan lansia ini akan terjadi suatu proses yang disebut Aging Process atau proses penuaan. Usia lanjut sebagai 
tahap akhir siklus kehidupan merupakan tahap perkembangan normal yang akan dialami oleh setiap individu yang mencapai usia lanjut. Hal tersebut merupakan suatu kenyataan yang tidak dapat dihindari oleh setiap manusia ${ }^{1}$.

Proporsi penduduk di atas 60 tahun di dunia diperkirakan akan terus meningkat. Perkiraan peningkatan dari tahun 2000 sampai 2050 akan berlipat ganda dari sekitar $11 \%$ menjadi $22 \%$, atau secara absolut meningkat dari 605 juta menjadi 2 milyar lansia². Dari tahun 2010-2014 pertumbuhan penduduk Indonesia setiap tahun terus meningkat, dari 3,54 juta per tahun menjadi 3,70 juta per tahun. Saat ini Jumlah penduduk usia lanjut Berkisar antara 27 juta (angka nasional), dan diprediksi pada tahun 2020 akan menjadi sekitar 38 juta atau $11,8 \%$ dari seluruh jumlah penduduk usia lanjut ${ }^{3}$.

Usia lanjut pada umumnya
mengalami berbagai perubahan.

Perubahan tersebut antara lain adalah kematian pasangan, kerusakan fungsi, dan penyakit kronik, sikap dan pandangan negatif terhadap kondisi menua, masa pensiun, kematian keluarga dan teman, dan relokasi dari tempat tinggal keluarga. Perubahan ini akan memberikan pengaruh pada seluruh aspek kehidupan, termasuk kesehatannya. Perubahan psikis para lansia meliputi perubahan dalam hal belajar, berfikir, kreativitas, ingatan, rasa humor. Perubahan dalam aspek motorik terjadi pada kemampuan kecepatan, kekuatan, belajar keterampilan baru, dan kekakuan ${ }^{4}$.
Permasalahan-permasalahan

tersebut mencakup pada aspek biologis, spiritual dan emosional yang terjadi pada lansia. salah satu permasalahan yang terjadi terhadap penduduk lansia adalah terjadinya degradasi nilai-nilai norma dalam penanganan lansia dari sebagian masyarakat yang kurang respect terhadap lansia. Hal ini terjadi karena memang sebagian masyarakat mengganggap bahwa lansia hanyalah penambah beban keluarga saja. Tidak sedikit juga masyarakat lebih memilih membawa lansia ke panti jompo daripada mengurus di rumah sendiri.

Terjadinya permasalahan fungsi fisik dan psikis pada lansia tersebut memungkinkan lansia membutuhkan orang lain untuk mendukung dan membantunya melakukan aktivitas kehidupan sehari-hari. Ketika lansia merasa terbatas pada kemampuan fisiknya, ia membutuhkan orang lain untuk membantunya, ia merasa tidak berguna dan terhambat dalam mengaktualisasikan potensi yang ia miliki untuk mencapai segala yang ia inginkan.

Kejadian hidup ataupun peristiwaperistiwa yang merugikan merupakan penentu utama penyakit-penyakit psikiatrik pada lansia. Kehilangan teman-teman dan orang-orang yang dicintai menyebabkan terjadinya isolasi sosial atau dengan kata lain lansia cenderung menarik diri dari lingkungan sosialnya. Kehilangan anak, atau pasangan merupakan faktor risiko penting lansia mengalami depresi. Hoyer \& Roodin ${ }^{5}$ menyebutkan bahwa sekitar $15 \%$ lansia mengalami kesulitan-kesulitan besar 
dalam penyesuaian diri terhadap pengunduran diri. Hal ini mengakibatkan lansia sering mengalami berbagai masalahmasalah didalam kehidupannya dari segi kesehatan secara jasmani maupun rohani.

\section{METODE}

Kegiatan yang dilakukan adalah dengan memberikan program lansia asik, aktif dan produktif dipanti sosial tresna werdha budi luhur jambi. Ada 3 metode yang digunakan dalam program ini. Program pertama yang dilakukan adalah jalan santai sebgai intervensi hipertensi pada lansia. Kegiatannya adalah mengajak lansia jalan kaki selama 5 menit, kegiatan ini membantu lansia yang hipertensi mengubah gaya hidup dengan berolahraga ringan. Pada usia senja tidak dimungkinkan untuk melakukan olahraga yang berlebhian dikarenakan kondisi fisik, biologis yang tidak mendukung. Oleh karena itu cukup dengan jalan selama 5 menit saja.

Pengaruh berolah raga khususnya jalan kaki terhadap penurunan tekanan darah dapat mencegah dan mengurangi komplikasi kardiovaskuler, hal ini disampaikan oleh organisasi The Amirican Heart Association, the Amirican College of Sports Medicine, the Surgeon General of the Unit-cardiorespied States telah mengelurkan pernyataan yang mendukung peran aktivitas fisik atau olah raga sebagai pengobatan non farmakologis pada hipertensi. telah banyak penelitian sebelumhya yang mendukung pernyataan bahwa aktivitas fisik berpengaruh terhadap tekanan darah pada hipertensi.
Program kedua yang diberikan yaitu berupa program tekhnik relaksasi dalam penerimaan hidup lansia. Berdasarkan data yang diperoleh dari berbagai sumber menunjukkan bahwa kesadaran akan pentingnya spiritual di kalangan lansia masih sangat rendah. Hal ini ditandai dengan minimnya penerimaan diri bagi para lansia dimasa tuanya. Hal ini tentu berdampak pada kesehatan mental bagi lansia. Untuk itu perlu dilakukan intervesi dalam upaya membantu permasalahan yang mereka hadapi. Selain itu, keterbatasan akan pengetahuan dan wawasan mengenai kesehatan mental di kalangan lansia pun menjadi salah satu pemicu rendahnya tingkat kesadaran lansia untuk mendapatkan pertolongan secara psikologis.Adapun program intervensi yang akan diberikan kepada lansia, adalah progam “RELAX yuk!”. Program ini adalah pemberian pelatihan relaksasi untuk lansia.

Program terakhir Program Psikoedukasi dukungan keluarga lansia terhadap emosional lansia. keharmonisan antara individu dengan lingkungannya, perasaan hangat dan damai dalam lingkungan keluarga dapat memberikan kebahagiaan dan ketentraman dalam hati anggota keluarga tersebut termasuk lansia. Akan tetapi sebaliknya, jika lingkungan keluarga tidak lagi bisa memberikan kenyamanan, kehangatan dan penerimaan sosial yang baik terhadap lansia, maka bisa jadi yang mucul adalah depresi. Hasil studi juga menemukan salah satu peristiwa yang membahagiakan dalam kategori relasi 
dengan keluarga adalah pada saat kelahiran anak dan cucu.

\section{Keluarga merupakan Support} System utama bagi lanjut usia dalam mempertahankan kesehatannya. peranan keluarga dalam perawatan lanjut usia antara lain merawat dan menjaga lanjut usia, mempertahankan dan meningkatkan status mental, mengantisipasi perubahan sosial ekonomi serta memberikan motivasi dan memfasilitasi kebutuhan lanjut usia (Maryam, dkk, 2008). Oleh karena itu dukungan keluarga sangat penting bagi lanjut usia. Program yang saya rancang dalam permasalahan ini ialah psikoedukasi dukunga keluarga dengan program" ASIA (Aktif bersama lanSia)". Program ini bertujuan untuk membangung dukungan keluarga terhadap lansia dengan kegiatankegiatan sederhana yang membangun kembali keintiman dengan lansia.

\section{HASIL DAN PEMBAHASAN}

Program lansia asik, lansia aktif dan lansia produktif telah dilaksanakan pada tanggal 30 agustus 2020. Kegiatan tersebut diantaranya yaitu jalan santi 5 menit, ice breaking, relax yuk yaitu pemberian terapi relaksasi, memberkan motivasi dan edukasi, makan bersama, penampilan bersama lansai, serta bercerita bersama lansia.

Panitia yang melaksanakan kegiatan ini berjumlah 8 orang yang terdiri dari dua dosen dan 6 orang mahasiswa Program Studi Psikologi FKIK Universitas Jambi. Materi disampaikan oleh Semita Dhiya An-Najwa Dan Renti Wulan Sari.
Pemateri merupakan mahasisswa universitas jambi yang tergabung dalam Unit Training And Motivation Center Universitas Jambi. Kegiatan diikuti oleh 50 lansia yang masih aktif dipanti tresna werdha budi luhur jambi.

Seluruh peserta dikumpulkan terlebih dahulu dilapangan melakukan senam pagi selama 5 menit saja. kemudian diarahkan untuk berjalan santai selama 5 menit menuju aula tempat kegiatan. Sesampainya diaula para lansia diberikan sarapan kemudian pembukaan perkenalan dan bincang santai untuk menbangun keintiman dengan lansia. Setelah itu dilanjutkan dengan program kedua, program ini terbagi menjadi tiga sesi yaitu sebagai berikut ;

1. Sesi "Mengenal Lansia". Pada sesi ini, peserta akan diberikan penjelasan dan pemahaman mengenai perkembangan psikologis lansia, baik secara kognitif,afektif, maupun sosial. Sesi ini dilakukan dengan metode ceramah dan tanya jawabsebagai bagian dari program psikoedukasi bagi peserta. Waktu yang dibutuhkanuntuk pelaksanaan sesi ini yaitu sekitar 45 menit.

2. Sesi "Permasalahan yang Sering Muncul pada Lansia serta Penanganannya". Sesi kedua dilakukan dengan membagi lansia menjadi beberapa kelompok.kemudian melakukan proses konseling dengan berbagi cerita dan pengalaman antar lansia. 
Sesi ini dilakukan dengan metode ceramah dan juga tanya jawab. Waktu yang dibutuhkan untukpelaksanaan sesi ini yaitu sekitar 45 menit;

3. Sesi "Pelatihan Relaksasi". Sesi terakhir dari program intervensi yang diberikan yaitu pelatihan relaksasi bagi parapeserta. Pelatihan ini didahului dengan ceramahkemudian dilanjutkan dengan mndengarkan instrument music klasik dan renungan Lalu diikuti dengan tanya jawab dari peserta.

Setelah itu dilanjutkan dengan program ketiga kegiatannya berupa Makan bersama lansia, Bermain games sederhana bersama lansia, Ice breaking bersama lansia, dan bernyanyi bersama lansia.

\section{KESIMPULAN}

Kegiatan pengabdian masyarakat ini telah berhasil dilaksanakan. Beberapa kegiatan yang telah dilakukan yaitu Lansia dipanti werdha mampu menerapkan program yang telah diberikan secara aktif, Lansia mampu melakukan kegiatan produktif yang akan difasilitasi oleh komunitas PONDASI, Meningkatkan kesehatan serta pencegahan penyakit hipertensi pada lansia, Meningkatkan spritulitas lansia dipanti sosial tresna werdha budi luhur jambi, Mampu meningkatkan emosional lansia kearah yang positif dan menjadi lansia yang berkualitas.

Dilihat dari respon peserta, kegiatan ini memberikan banyak perubahan dan manfaat bagi lansia diantaranya Agar lansia memliki kualitias hidup yang tinggi dengan begerak aktif dan emosional yang stabil, Memberikan lansia motivasi agar dapat menerima kondisi dihari tua saat ini, Agar lansia menjadi sehat baik secara mental maupun fisik, Unutk membangn kedekatan terhadpa lansia.

\section{DAFTAR PUSTAKA}

1. Notoatmodjo. 2014. Pendidikan dan perilaku kesehatan. Jakarta: EGC.

2. WHO. Mental health of older adults. 2017

3. Kementrian Kesehatan Republik Indonesia. 2017. ANALISIS LANJUT USIA DIINDONESIA. Infodatin. Jakarta selatan

4. Hurlock, E.B. 2011. Psikologi Perkembangan. Jakarta: Erlangga.

5. Hoyer, William J., Paul A. Roodin. 2003. Adult Development and Aging, 5th edition. New York: Mc Graw and Hill.

6. Maryam, R. Siti, dkk. (2008). Mengenal Usia lanjut dan Perawatannya. Jakarta : Salemba Medika. 